\title{
The Impact of Cytochrome P450 3A5 Genotype on Early Tacrolimus Metabolism and Clinical Outcomes in Lung Transplant Recipients
}

\section{Wenwen Du}

China-Japan Friendship Hospital

\section{Xiaoxing Wang}

China-Japan Friendship Hospital

\section{Dan Zhang}

China-Japan Friendship Hospital

Wenqian Chen

China-Japan Friendship Hospital

\section{Xianglin Zhang}

China-Japan Friendship Hospital

Pengmei Li ( $\square$ lipengmei@yeah.net)

China-Japan Friendship Hospital

\section{Research Article}

Keywords: Tacrolimus, Lung transplantation, CYP3A5 genotype, Mortality, AKI

Posted Date: August 10th, 2021

DOI: https://doi.org/10.21203/rs.3.rs-782512/v1

License: @ (1) This work is licensed under a Creative Commons Attribution 4.0 International License. Read Full License

Version of Record: A version of this preprint was published at International Journal of Clinical Pharmacy on December 3rd, 2021. See the published version at https://doi.org/10.1007/s11096-021-01359-3. 


\section{Abstract}

Background Tacrolimus (Tac) is the cornerstone of immunosuppressant therapy after lung transplantation (LTx). It shows great interindividual variability in pharmacokinetics, which could partly be explained by pharmacogenetic factors.

Objective We aim to investigate the effect of cytochrome P450 3A5 (CYP3A5) (rs776746) genotypes on early post-operative Tac metabolism and clinical outcomes in LTx recipients.

Methods 90 recipients who underwent LTx from 2017 to 2019 at our institution were enrolled in the study. The effect of CYP3A5 genotype on Tac concentration, dose, dose adjusted concentration (C/D) and interaction with azole antifungals were assessed during week 1-4 after transplantation. Associations between CYP3A5 genotype and the incidence of acute kidney injury (AKI), length of hospital stay and mortality were analyzed.

Results CYP $3 A 5^{\star} 1$ carriers had lower C/D than CYP $3 A 5^{\star} 3 /{ }^{*} 3$ group at all time points $(p<0.05)$. To reach comparable blood concentrations, $C Y P 3 A 5^{\star} 1$ carriers required higher doses compared with $C Y P 3 A 5^{\star} 3 /{ }^{*} 3$ group $(p<0.05)$. Use of azole antifungals did not blunt the effect of CYP3A5 genotypes on Tac metabolism. Logistic regression showed Tac concentration at week 1, not CYP3A5 genotype, was associated with the incidence of AKI. No statistically significant difference was found between CYP3A5 genotypes and the length of hospital stay (48 (37-68) vs $46(32-57)$ days, $p=0.264)$. Kaplan-Meier analysis showed no statistically significant difference between 30-day or 1-year mortality and CYP3A5 genotype.

Conclusion CYP3A5 genotype could affect Tac metabolism early after LTx. However, it has no influence on the incidence of AKI, length of hospital stay and mortality.

\section{Impacts On Practice}

- Genetic polymorphism of $C Y P 3 A 5 * 3$ could affect tacrolimus metabolism early after lung transplantation and hence may provide information in determining personalized dosing of tacrolimus.

- To achieve target concentration, $C Y P 3 A 5^{\star} 3 /{ }^{*} 3$ carriers require lower doses compared with $C Y P 3 A 5^{\star} 1$ carriers, regardless of use of azole antifungals or not.

- Genetic polymorphism of $C Y P 3 A 5 * 3$ does not seem to be directly associated with incidence of $\mathrm{AKI}$ and mortality in lung transplant recipients.

- Rather than considering CYP3A5*3 genotype, paying more attention to tacrolimus concentration at week 1 seems more important in determining patient at higher risk of AKI after lung transplantation.

\section{Introduction}

Tacrolimus (Tac) is the cornerstone of immunosuppressant therapy after lung transplantation (LTx) [1]. It is essential to reach target range of Tac concentration as soon as possible in the early post-transplant period, since erratic concentration may increase the incidence of rejection [2], nephrotoxicity [3] and even affects mortality [4]. However, this attempt is usually hampered by its highly variable pharmacokinetics [5]. Thus, extensive monitoring of whole blood concentration is required for dose adjustment, which consumes time and resources, and adds economic burden and physical pain to patients [6].

As a supplement to routine concentration monitoring, pharmacogenetics may provide guidance information for Tac dosage adjustment. Tac is mainly metabolized by cytochrome P450 (CYP) 3A5 after oral administration [7]. CYP3A5*3 (rs776746) mutation results in nonfunctional protein, leading to decreased CYP3A5 activity [8]. And hence, $C Y P 3 A 5 * 3 / * 3$ genotype carriers are reported to require lower doses, and exhibit higher dose adjusted trough concentration (C/D) of Tac when compared to CYP3A5*1 carriers in kidney [9], liver [10], and heart transplantation recipients [11]. In LTx, similar results have been reported in Caucasians [12-14]. But studies in Chinese population are limited till now $[15,16]$, and Chinese has a different mutation rates of $C Y P 3 A 5^{\star} 3$ from Caucasians $[6]$, so, there is a major void in this research area.

\section{Aim of the study}

Our study was designed to investigate two key questions. First, whether CYP3A5 genotype plays a role in inter-individual variability of Tac metabolism early after LTx. Second, whether there is association between CYP3A5 genotype and clinical outcomes. 


\section{Ethics approval}

All procedures in this study were in accordance with the 1964 Helsinki declaration and its amendments, and was approved by the Ethics Committee of China-Japan Friendship Hospital in May, 2019 (No. 2019-65-K45). All recipients signed informed consent when undergoing lung transplantation, in which they gave permission for use of anonymized medical data by scientists.

\section{Methods}

\section{Patients}

Recipients who undergone LTx during 2017 to 2019 in China-Japan Friendship Hospital were enrolled in this study. The inclusion criteria were: (1) LTx for the first time; (2) received Tac-based immunosuppressive regimen; (3) age $\geq 18$. The exclusion criteria were: (1) received cyclosporin in the first month; (2) survived less than $24 \mathrm{~h}$ after surgery.

\section{Immunosuppressive and anti-fungal regimens}

Per protocol in our center, most recipients used a triple maintenance immunosuppressive regimen consisting of Tac, mycophenolate mofetil (MMF) and prednisone. Tac was given on post-operative day (POD) 1. Starting dose was $2 \mathrm{mg} / \mathrm{d}$ in 2 divided doses, except those with exceptionally high or low body weight were given a personalized dose per attending physician's judgement. Dose adjustments were made according to whole-blood trough concentration, determined using micro-particle enzyme immunoassay (ARCHITECT i1000SR immunoassay analyzer, Abbott U.S.). The target range of concentration was $8-10 \mathrm{ng} / \mathrm{mL}$ in the first month after LTx. The initial dose of MMF was $1000 \mathrm{mg} / \mathrm{d}$ in 2 divided doses. Dose adjustments were made based on area under curve (AUC) calculations. Prednisone was given intravenously at $1 \mathrm{mg} / \mathrm{kg} / \mathrm{d}$ during POD $1-3$, and then switched to oral administration at $0.5 \mathrm{mg} / \mathrm{kg} / \mathrm{d}$, and gradually tapered to 5 $10 \mathrm{mg} / \mathrm{d}$ for long-term maintenance.

In addition to immunosuppressive therapy, voriconazole or posaconazole were administrated for prophylaxis or treatment of invasive aspergillus. Voriconazole was started with a loading dose of $800 \mathrm{mg} / \mathrm{d}$ divided in $2 \mathrm{doses}$, either intravenous or oral. Then dose adjustments were made according to trough concentration measurements and maintenance dose was 300-400 mg/d. Posaconazole was given in suspensions, and started at $800 \mathrm{mg} / \mathrm{d}$, in 4 divided doses. Then dose adjustments were made according to trough concentration and maintained at 600 or $800 \mathrm{mg} / \mathrm{d}$, in 3 or 4 divided doses, respectively.

\section{Genotype Determination}

Genotypes of $C Y P 3 A 5^{\star} 3$ were determined using Sanger Sequencing. Briefly, genomic DNA was extracted from EDTA-anticoagulated peripheral whole blood samples by a commercially available DNA purification kit (EasyPure Blood Genomic DNA Kit, Transgene Biotech, Beijing, China). DNA samples were sequenced by the ABI 3730XL DNA Sequencer (ABI Co; Majorbio Biotechnology Co.,Ltd., Beijing, China).

\section{Data collection}

Patients' data were extracted by reviewing electronic medical records. Information including basic demographics (age, sex, height, weight, diagnosis, comorbidities, and transplant type), baseline laboratory test results (serum creatinine (SCr), anine aminotransferase (ALT), aspartate aminotransferase (AST), total bilirubin (Tbil), direct bilirubin (Dbil), urea, uric acid, red blood cells (RBC), hemoglobin, hematocrit, and glucose) and post-operative data (Tac dose ( $\mathrm{mg} / \mathrm{d})$, corresponding body weight $(\mathrm{kg})$, trough concentration $(\mathrm{ng} / \mathrm{mL})$, use of azole antifungals (voriconazole or posaconazole), and SCr) were obtained. Dose adjusted concentration (C/D, ng/mL per mg/kg/d) was calculated by dividing concentration by the corresponding body weight adjusted daily dose $(\mathrm{mg} / \mathrm{kg} / \mathrm{d})$.

\section{Outcome definitions}

Pharmacokinetic outcomes of interest were Tac concentration, dose, and C/D. Clinical outcomes were incidence of AKI, length of hospital stay, 30-day and 1-year mortality. AKI was determined and staged according to the 'Kidney Disease: Improving Global Outcomes' (KDIGO) Clinical Practice Guideline, basing on SCr obtained from the transplantation day until 7 days after transplantation [17].

\section{Statistical analysis}


The normality distribution of data was assessed using the Shapiro-Wilk test. Chi-square test was performed to assess the deviation of gene frequencies from Hardy-Weinberg equilibrium. Descriptive statistics were expressed as mean \pm standard deviation (SD) for normally distributed continuous variables or median (interquartile range, IQR) for non-normally distributed continuous variables. Categorical variables were presented as count (percentage). Comparisons between continuous variables were analyzed by Student's $t$ test or Mann-Whitney U test. Pearson's chi-square test or Fisher's exact test was used to compare differences in categorical variables. Logistic regression was performed to study factors associated with incidence of AKI. Potential risk factors with a $p<0.20$ in univariate analysis were incorporated into multivariate logistic regression, which adopts a forward LR strategy. 30-day and 1-year survival rates stratified by CYP3A5 genotype was analyzed by Kaplan-Meier analysis and compared using the log-rank test. $P<0.05$ was considered of statistical significance. Data was processed using Statistical Package for Social Science (SPSS) 19.0.

\section{Results}

\section{Patients' characteristics}

During 2017 and 2019, 150 patients received LTx. From this study population, 51 were excluded due to not available for genetic testing, 3 were excluded due to missing data, 3 were excluded due to use of cyclosporin, 2 were excluded for death within 24 hours and 1 was excluded due to less than 18 years old, leaving 90 for final analysis. Table 1 shows the demographics of the study population. Median (IQR) age was 60 (56-64) years old, and male patients (87.8\%) accounted for a large proportion. Median (IQR) hospital stay length was 46 (35-60) days and follow-up time was 1 year.

For CYP3A5 genotypes, $* 1 / * 1, * 1 / * 3$ and $* 3 / * 3$ were detected in 6,36 and 48 patients, respectively. The frequency of CYP3A5 genotypes were in accordance with Hardy-Weinberg equilibrium $(p>0.05)$. CYP $3 A 5^{*} 1$ carriers and $C Y P 3 A 5 * 3 / * 3$ group differ in baseline BMI, Dbil and pre-operative diabetes mellitus status.

\section{Influence of CYP3A5 genotype on Tac metabolism}

Fig. 1 a shows the Tac concentration trend-lines of all patients. Individual concentration fluctuated considerably in the early postoperative period, with only a small portion of patients reaching the target range on POD 3 after receiving a standardized starting dose.

CYP $3 A 5^{\star} 1$ carriers exhibited statistically significant lower concentration level than CYP3A5*3/*3 group (3.8 (1.9-9.6) vs 8.8 (5.2-12.7) $\mathrm{ng} / \mathrm{mL}, p<0.001)$ (Fig. 1b) at comparable dose levels $(2.0(2.0-3.5)$ vs $2.0(1.6-3.0) \mathrm{mg} / \mathrm{d}, p=0.221)$ in week 1 (Fig. $1 \mathrm{c})$. Lower C/D in CYP3A5 $^{\star} 1$ carriers were observed at all time points: week $1(\mathrm{n}=81), 80.58(46.94-144.58)$ vs $232.27(137.29-406.82) \mathrm{ng} / \mathrm{mL} \mathrm{per}$ $\mathrm{mg} / \mathrm{kg} / \mathrm{d}, p<0.001$; week $2(\mathrm{n}=84), 105.48(63.91-219.46)$ vs $233.44(131.70-521.40) \mathrm{ng} / \mathrm{mL} \mathrm{per} \mathrm{mg/kg/d}, p<0.05 ;$ week $3(\mathrm{n}=86)$, $89.15(58.82-294.00)$ vs $212.52(123.17-552.00) \mathrm{ng} / \mathrm{mL}$ per $\mathrm{mg} / \mathrm{kg} / \mathrm{d}, p<0.001$; and week $4(\mathrm{n}=81), 105.30(50.41-245.98)$ vs 229.26 $(129.58-435.30) \mathrm{ng} / \mathrm{mL}$ per $\mathrm{mg} / \mathrm{kg} / \mathrm{d}, p<0.05)$ (Fig. 1d).

\section{Relationship between azole antifungals, CYP3A5 genotype and Tac metabolism}

Patients who underwent concomitant azole antifungals and Tac therapy showed significantly lower dose requirements and higher $\mathrm{C} / \mathrm{D}$ of Tac at week 1-4 (Table 2) compared to those who received Tac only. When further stratified by CYP3A5 genotype, CYP $3 A 5^{\star} 1$ carriers still showed lower C/D than CYP3A5*3/*3 group at all time points (Fig. 2): week 1 without antifungals $(\mathrm{n}=70), 72.45(42.47-131.41)$ vs 210.06 (129.75-323.30) $\mathrm{ng} / \mathrm{mL}$ per $\mathrm{mg} / \mathrm{kg} / \mathrm{d}, p<0.001$; week 1 with antifungals $(\mathrm{n}=11), 417.60$ (189.23-449.50) vs 970.70 (790.95$1311.10) \mathrm{ng} / \mathrm{mL}$ per $\mathrm{mg} / \mathrm{kg} / \mathrm{d}, p<0.05$; week 2 without antifungals $(\mathrm{n}=67), 79.27(61.08-184.27) \mathrm{vs} 176.07(110.55-266.98) \mathrm{ng} / \mathrm{mL}$ per $\mathrm{mg} / \mathrm{kg} / \mathrm{d}, p<0.05$; week 2 with antifungals $(\mathrm{n}=17), 467.50(220.80-745.20)$ vs $957.60(696.48-1266.60) \mathrm{ng} / \mathrm{mL} \mathrm{per} \mathrm{mg} / \mathrm{kg} / \mathrm{d}, p<$ 0.05 ; week 3 without antifungals $(\mathrm{n}=63), 61.50(57.29-143.08)$ vs $132.00(112.71-237.73) \mathrm{ng} / \mathrm{mL}$ per $\mathrm{mg} / \mathrm{kg} / \mathrm{d}, p<0.001$; week 3 with antifungals $(\mathrm{n}=23), 320.17(174.00-459.20)$ vs $881.87(704.30-1154.25) \mathrm{ng} / \mathrm{mL}$ per $\mathrm{mg} / \mathrm{kg} / \mathrm{d}, p<0.001$; week 4 without antifungals ( $\mathrm{n}$ = 55), $60.23(46.84-149.24)$ vs $160.34(95.36-246.67) \mathrm{ng} / \mathrm{mL}$ per $\mathrm{mg} / \mathrm{kg} / \mathrm{d}, p<0.001$; week 4 with antifungals $(\mathrm{n}=26), 324.30(207.80-$ $543.60)$ vs $753.40(435.30-961.13) \mathrm{ng} / \mathrm{mL}$ per $\mathrm{mg} / \mathrm{kg} / \mathrm{d}, p<0.05)$.

\section{Influence of CYP3A5 genotype on AKI}

Five variables, including age, baseline $\mathrm{SCr}$, uric acid, $\mathrm{RBC}$ and week 1 Tac concentration $\geq 7.5 \mathrm{ng} / \mathrm{mL}$, showed $p<0.20$ in univariate analysis and were further assessed in multivariate model (Table 3). Only week 1 Tac concentrations $\geq 7.5 \mathrm{ng} / \mathrm{mL}(\mathrm{OR} 5.38 ; 95 \% \mathrm{Cl} 1.40-$ $20.69 ; p=0.014$ ) was associated with increased risk of AKI. CYP3A5 genotype showed no significance in both univariate and multivariate analysis. 


\section{Influence of CYP3A5 genotype on length of hospital stay and mortality}

Of our study population, no statistically significant difference was observed in the length of hospital stay between $C Y P 3 A 5^{\star} 1$ carriers and $* 3 / * 3$ group: $48(37-68)$ vs $46(32-57) \mathrm{d}, p=0.264$.

Thirty-day and 1-year survival rates of the study population were $94.4 \%$ and $88.9 \%$, respectively. According to Kaplan-Meier analysis, although $C Y P 3 A 5^{\star} 1$ carriers showed higher survival rates than $* 3 / * 3$ group at both 30 -day $(97.6 \%$ vs $91.7 \%)$ and 1 -year $(92.9 \%$ vs $85.4 \%)$, no statistical significance were achieved ( $p=0.367$ and $p=0.433$, respectively) (Fig. 3).

\section{Discussion}

\section{Statement of key findings}

In this study, the influence of CYP3A5 genotype on Tac metabolism and clinical outcomes in Chinese LTx population was discussed. We drew three major conclusions from the data: (1) patients bearing CYP3A5*1 allele showed significantly lower Tac C/D and higher dose requirement compared with $* 3 / * 3$ genotype in the early post-operative period; (2) the use of azole antifungals did not change the influence of CYP3A5 genotype on Tac metabolism; (3) CYP3A5 genotype has no effect on the incidence of AKI, length of hospital stay or mortality.

The frequency of $C Y P 3 A 5^{*} 3$ variant differs among world populations, which is estimated to be $94,68-71$ and $18 \%$ in Europeans, Asians, and Africans, respectively [6]. The mutation rate in this study was $73 \%$, comparable to previous studies in Chinese transplant recipients $[16,18]$.

A meta-analysis summarized that Tac $\mathrm{C} / \mathrm{D}$ in kidney transplant recipients with $C Y P 3 A 5^{\star} 3 /{ }^{*} 3$ genotype was $1.8-2.5$ times higher than CYP $3 A 5^{*} 1$ carriers during the first year after transplantation [19]. Similar conclusions were also drawn in liver and heart transplant recipients $[11,20,21]$. Compared with other types of solid organ transplantation, studies concerning CYP3A5 genotype in LTx population are limited $[4,13]$. In Caucasians, Miano et al reported patients bearing CYP3A5*3/*3 genotype exhibited approximately 50\% higher C/D than $C Y P 3 A 5^{\star} 1$ carriers in the first 2 weeks after LTx [13] and Zheng et al investigated later time points, from 1 month to 12 months, and also observed higher C/D in CYP3A5*3/*3 [4]. Only 1 study conducted in Chinese with a relatively small sample size of 51 recipients reported the C/D for $C Y P 3 A 5^{\star} 3 /{ }^{*} 3$ genotype was $1.9-2.5$ times higher than $C Y P 3 A 5^{\star} 1$ carriers in the first month [16]. In our study, the C/D for $C Y P 3 A 5 * 3 / * 3$ vs. CYP $3 A 5^{\star} 1$ carriers were $2.88,2.21,2.38$ and 2.18 during week $1-4$, respectively, similar to the results from both Caucasian and Chinese population.

Considering the difference in Tac-metabolizing activity, the 2015 Clinical Pharmacogenetics Implementation Consortium (CPIC) guideline and 2019 Therapeutic Drug Monitoring (TDM) consensus report have suggested using approximately 1.5-2 times higher starting dose for $C Y P 3 A 5^{\star} 1$ carriers in order to reach the same target concentration as $C Y P 3 A 5^{*} 3 /{ }^{*} 3$ genotype $[1,6]$. Due to the retrospective nature of our study, we could not control the initial dose of Tac, but, still, we found the dose requirement of $C Y P 3 A 5^{\star} 1$ carriers was $1.7-2.4$ times higher than CYP3A5*3/*3 when comparable concentrations were achieved (Fig. 1b and 1c). Therefore, genotyping of CYP3A5 before Tac treatment may offer useful information in determining individualized dose [22].

Azole antifungals (voriconazole or posaconazole), often concomitantly used with Tac due to the high incidence of invasive aspergillosis after LTx, can increase Tac C/D by inhibiting CYP3A enzymes [14, 23]. Previous studies have reported a major drug-drug interaction between Tac and azole antifungals in both $C Y P 3 A 5^{*} 1$ carriers and $C Y P 3 A 5^{*} 3 / * 3$ group, and leads to significantly higher Tac $\mathrm{C} / \mathrm{D}$ in lung and kidney transplant recipients $[14,24]$. We also observed elevated Tac C/D in patients using azole antifungals. Moreover, $C Y P 3 A 5 * 3 / * 3$ group still exhibited higher $\mathrm{C} / \mathrm{D}$ and lower dose requirement compared with $C Y P 3 A 5^{\star} 1$ carriers (Fig. S1 and S2) regardless of using azole antifungals or not, suggesting the effect of CYP3A5 genotype on Tac metabolism was not blunted by azole antifungals.

We further explored if a direct association exists between CYP3A5 genotype and clinical outcomes. Since CYP3A5 is expressed in the kidney, it is plausible to hypothesize that the genetic variability in CYP3A5 expression and activity may affect the metabolism of Tac in kidney tubular cells, and therefore, may correlate with its nephrotoxicity $[25,26]$. However, In analysis of risk factors of AKI, Tac concentration $\geq 7.5 \mathrm{ng} / \mathrm{mL}$ in the first week, not CYP3A5 genotype, was associated with the incidence of AKI. Similarly, Woodahl et al reported no correlation between $C Y P 3 A 5$ genotype and AKI in hematopoietic cell transplantation recipients [27]. Calabrese et al investigated the impact of CYP3A5, CYP3A4, and ABCB1 genotypes on AKI in $321 \mathrm{LTx}$ recipients and found no difference among different CYP3A genotypes [14]. One possible explanation for the lack of correlation is common genetic polymorphisms of $C Y P 3 A 5$ did 
not reflect its expression profile in kidney. The location and expression of renal CYP3A5 might be the actual contributor to the nephrotoxicity of Tac [28].

CYP3A5 genotypes did not alter the length of hospital stay in LTx recipients. Previous study has reported increased hospital stay in kidney transplant recipients with $C Y P 2 C 19 * 2 / 2$ genotype [29]. Bosó et al explained the difference was directly correlated with higher median Tac C/D during the first week after transplant. Judging from our data, CYP3A5*3/*3 group also exhibited higher median Tac C/D at week 1 , however, no difference in hospital stay were found between genotypes. Considering the small number of patients ( $\mathrm{n}=4$ in CYP2C19*2/*2 group) in Bosós study, the correlation might lack potency and needs further validation. Furthermore, no correlation between CYP3A5 genotype and mortality was found, which is in consistence with previous study in kidney and heart transplant population $[11,30]$.

\section{Strengths And Weaknesses}

In summary, despite the large number of studies addressing the influence of CYP3A5 genotype on Tac metabolism, whether it plays a role in clinical outcomes remains controversial. Several meta-analysis and studies have reported no significant association between CYP3A5 genotype and adverse outcomes [31, 32]. Besides, Tac C/D has been proposed as a stronger prognostic marker for poor outcomes recently. Though closely related to CYP3A5 genotype, Tac C/D is also affected by other factors, including the use of corticosteroids and non-adherence, and therefore, may be better in reflecting immunosuppressive status [33, 34].

There are certain limitations in our study. First, this is a retrospective study with a relatively small sample size, therefore, the conclusions may need confirmation in prospective studies. Second, our population mainly consists of male adults, limited females and no pediatric patients were included. They may possess different physiological characteristics, such as liver function, hemoglobin concentration and hematocrits, and hence further studies in a more diverse population are warranted.

\section{Conclusions}

In this study, we investigated the influence of CYP3A5 genotype on Tac metabolism and clinical outcomes in Chinese LTx recipients. As with other types of transplantation, $C Y P 3 A 5^{\star} 1$ carriers exhibited significantly lower $\mathrm{C} / \mathrm{D}$ and higher dose requirements compared to $C Y P 3 A 5 * 3 / * 3$ group in the early post-operative period. Concomitant use of azole antifungals did not blunt the influence of $C Y P 3 A 5$ genotype on Tac metabolism. We also found CYP3A5 genotype was not associated with clinical outcomes, including incidence of AKI, length of hospital stay, 30-day and 1-year mortality.

\section{Declarations}

Funding The study was financed with National Key Research and Development Program of China (No.2020YFC2005504). The funding source had no effect on any part of the study, preparation, or submission of the manuscript.

Conflicts of interest All authors report no conflict of interest.

Funding The study was financed with National Key Research and Development Program of China (No.2020YFC2005504). The funding source had no effect on any part of the study, preparation, or submission of the manuscript.

Conflicts of interest All authors report no conflict of interest.

Availability of data and material Upon reasonable request from the corresponding author.

Code availability Not applicable.

Authors' contributions DWW contributed to the design of the study. WXX collected the data. DWW and WXX analyzed the data. DWW, ZD and CWQ contributed to the preparation of the manuscript. ZXL and LPM revised the manuscript.

Ethics approval All procedures in this study were in accordance with the 1964 Helsinki declaration and its amendments, and was approved by the Ethics Committee of China-Japan Friendship Hospital (No. 2019-65-K45).

Consent to participate All recipients signed informed consent when undergoing Lung transplantation, in which they gave permission for use of anonymized medical data by scientists. 
Consent for publication All authors have approved the submission.

\section{References}

1. Birdwell KA, Decker B, Barbarino JM, Peterson JF, Stein CM, Sadee W, Wang D, Vinks AA, He Y, Swen JJ, Leeder JS, van Schaik R, Thummel KE, Klein TE, Caudle KE, MacPhee IA (2015) Clinical pharmacogenetics implementation consortium (CPIC) guidelines for CYP3A5 genotype and tacrolimus dosing. Clin Pharmacol Ther 98:19-24. http://doi.org/10.1002/cpt.113

2. Gueta I, Markovits N, Yarden-Bilavsky H, Raichlin E, Freimark D, Lavee J, Loebstein R, Peled Y (2018) High tacrolimus trough level variability is associated with rejections after heart transplant. Am J Transplant 18:2571-2578. http://doi.org/10.1111/ajt.15016

3. Sikma MA, Hunault CC, van de Graaf EA, Verhaar MC, Kesecioglu J, de Lange DW, Meulenbelt J (2017) High tacrolimus blood concentrations early after lung transplantation and the risk of kidney injury. Eur J Clin Pharmacol 73:573580. http://doi.org/10.1007/s00228-017-2204-8

4. Zheng H, Zeevi A, Schuetz E, Lamba J, McCurry K, Griffith BP, Webber S, Ristich J, Dauber J, lacono A, Grgurich W, Zaldonis D, McDade K, Zhang J, Burckart GJ (2004) Tacrolimus dosing in adult lung transplant patients is related to cytochrome P4503A5 gene polymorphism. J Clin Pharmacol 44:135-140. http://doi.org/10.1177/0091270003262108

5. Staatz CE, Tett SE (2004) Clinical pharmacokinetics and pharmacodynamics of tacrolimus in solid organ transplantation. Clin Pharmacokinet 43:623-653. http://doi.org/10.2165/00003088-200443100-00001

6. Brunet M, van Gelder T, Åsberg A, Haufroid V, Hesselink DA, Langman L, Lemaitre F, Marquet P, Seger C, Shipkova M, Vinks A, Wallemacq P, Wieland E, Woillard JB, Barten MJ, Budde K, Colom H, Dieterlen MT, Elens L, Johnson-Davis KL, Kunicki PK, MacPhee I, Masuda S, Mathew BS, Millán O, Mizuno T, Moes DAR, Monchaud C, Noceti O, Pawinski T, Picard N, van Schaik R, Sommerer C, Vethe NT, de Winter B, Christians U, Bergan S (2019) Therapeutic drug monitoring of tacrolimus-personalized therapy: Second consensus report. Ther Drug Monit 41:261-307. http://doi.org/10.1097/FTD.0000000000000640

7. Hesselink DA, Bouamar R, Elens L, van Schaik RH, van Gelder T (2014) The role of pharmacogenetics in the disposition of and response to tacrolimus in solid organ transplantation. Clin Pharmacokinet 53:123-139. http://doi.org/10.1007/s40262-013-0120-3

8. Hustert E, Haberl M, Burk O, Wolbold R, He YQ, Klein K, Nuessler AC, Neuhaus P, Klattig J, Eiselt R, Koch I, Zibat A, Brockmöller J, Halpert JR, Zanger UM, Wojnowski L (2001) The genetic determinants of the CYP3A5 polymorphism. Pharmacogenetics 11:773779. http://doi.org/10.1097/00008571-200112000-00005

9. Yaowakulpatana K, Vadcharavivad S, Ingsathit A, Areepium N, Kantachuvesiri S, Phakdeekitcharoen B, Sukasem C, Sra-lum S, Sumethkul V, Kitiyakara C (2016) Impact of CYP3A5 polymorphism on trough concentrations and outcomes of tacrolimus minimization during the early period after kidney transplantation. Eur J Clin Pharmacol 72:277-283. http://doi.org/10.1007/s00228-015-1990-0

10. Coller JK, Ramachandran J, John L, Tuke J, Wigg A, Doogue M (2019) The impact of liver transplant recipient and donor genetic variability on tacrolimus exposure and transplant outcome. Br J Clin Pharmacol 85:2170-2175. http://doi.org/10.1111/bcp.14034

11. Liu BY, Chen WQ, Chen ZG, Huang J, Liao ZK, Liu Q, Zheng Z, Song YH, Wang W, Hu SS (2019) The effects of CYP3A5 genetic polymorphisms on serum tacrolimus dose-adjusted concentrations and long-term prognosis in Chinese heart transplantation recipients. Eur J Drug Metab Pharmacokinet 44:771-776. http://doi.org/10.1007/s13318-019-00563-x

12. Monchaud C, de Winter BC, Knoop C, Estenne M, Reynaud-Gaubert M, Pison C, Stern M, Kessler R, Guillemain R, Marquet P, Rousseau A (2012) Population pharmacokinetic modelling and design of a bayesian estimator for therapeutic drug monitoring of tacrolimus in lung transplantation. Clin Pharmacokinet 51:175-186. http://doi.org/10.2165/11594760-000000000-00000

13. Miano TA, Flesch JD, Feng R, Forker CM, Brown M, Oyster M, Kalman L, Rushefski M, Cantu E, 3rd, Porteus M, Yang W, Localio AR, Diamond JM, Christie JD, Shashaty MGS (2020) Early tacrolimus concentrations after lung transplant are predicted by combined clinical and genetic factors and associated with acute kidney injury. Clin Pharmacol Ther 107:462-470. http://doi.org/10.1002/cpt.1629

14. Calabrese DR, Florez R, Dewey K, Hui C, Torgerson D, Chong T, Faust H, Rajalingam R, Hays SR, Golden JA, Kukreja J, Singer JP, Greenland JR (2018) Genotypes associated with tacrolimus pharmacokinetics impact clinical outcomes in lung transplant recipients. Clin Transplant 32:e13332. http://doi.org/10.1111/ctr.13332

Page $7 / 14$ 
15. Cai X, Song H, Jiao Z, Yang H, Zhu M, Wang C, Wei D, Shi L, Wu B, Chen J (2020) Population pharmacokinetics and dosing regimen optimization of tacrolimus in Chinese lung transplant recipients. Eur J Pharm Sci 152:105448. http://doi.org/10.1016/j.ejps.2020.105448

16. Zhang X, Xu J, Fan J, Zhang T, Li Y, Xie B, Zhang W, Lin S, Ye L, Liu Y, Jiang G (2017) Influence of IL-18 and IL-10 polymorphisms on tacrolimus elimination in Chinese lung transplant patients. Dis Markers 2017:7834035. http://doi.org/10.1155/2017/7834035

17. Khwaja A (2012) KDIGO clinical practice guidelines for acute kidney injury. Nephron Clinical Practice 120:c179184. http://doi.org/10.1159/000339789

18. Tang HL, Xie HG, Yao Y, Hu YF (2011) Lower tacrolimus daily dose requirements and acute rejection rates in the CYP3A5 nonexpressers than expressers. Pharmacogenet Genomics 21:713-720. http://doi.org/10.1097/FPC.0b013e32834a48ca

19. Rojas L NI, Herrero MJ, Bosó V, Reig J, Poveda JL, Megías J, Bea S, Aliño SF (2015) Effect of CYP3A5*3 on kidney transplant recipients treated with tacrolimus: A systematic review and meta-analysis of observational studies. Pharmacogenomics 15:3848. http://doi.org/10.1038/tpj.2014.38

20. Buendia JA, Bramuglia G, Staatz CE (2014) Effects of combinational CYP3A5 6986A>G polymorphism in graft liver and native intestine on the pharmacokinetics of tacrolimus in liver transplant patients: A meta-analysis. Ther Drug Monit 36:442-

447. http://doi.org/10.1097/ftd.0000000000000032

21. Hendijani F, Azarpira N, Kaviani M (2018) Effect of CYP3A5*1 expression on tacrolimus required dose after liver transplantation: A systematic review and meta-analysis. Clin Transplant 32:e13306. http://doi.org/10.1111/ctr.13306

22. Andrews LM, Hesselink DA, van Schaik RHN, van Gelder T, de Fijter JW, Lloberas N, Elens L, Moes D, de Winter BCM (2019) A population pharmacokinetic model to predict the individual starting dose of tacrolimus in adult renal transplant recipients. Br $\mathrm{J}$ Clin Pharmacol 85:601-615. http://doi.org/10.1111/bcp.13838

23. Yamazaki H, Nakamoto M, Shimizu M, Murayama N, Niwa T (2010) Potential impact of cytochrome P450 3 A5 in human liver on drug interactions with triazoles. Br J Clin Pharmacol 69:593-597. http://doi.org/10.1111/j.1365-2125.2010.03656.x

24. Vanhove T, Bouwsma H, Hilbrands L, Swen JJ, Spriet I, Annaert P, Vanaudenaerde B, Verleden G, Vos R, Kuypers DRJ (2017) Determinants of the magnitude of interaction between tacrolimus and voriconazole/posaconazole in solid organ recipients. Am $\mathrm{J}$ Transplant 17:2372-2380. http://doi.org/10.1111/ajt.14232

25. Kuehl P, Zhang J, Lin Y, Lamba J, Assem M, Schuetz J, Watkins PB, Daly A, Wrighton SA, Hall SD, Maurel P, Relling M, Brimer C, Yasuda K, Venkataramanan R, Strom S, Thummel K, Boguski MS, Schuetz E (2001) Sequence diversity in CYP3A promoters and characterization of the genetic basis of polymorphic CYP3A5 expression. Nat Genet 27:383-391. http://doi.org/10.1038/86882

26. Dai Y, Hebert MF, Isoherranen N, Davis CL, Marsh C, Shen DD, Thummel KE (2006) Effect of CYP3A5 polymorphism on tacrolimus metabolic clearance in vitro. Drug Metab Dispos 34:836-847. http://doi.org/10.1124/dmd.105.008680

27. Woodahl EL, Hingorani SR, Wang J, Guthrie KA, McDonald GB, Batchelder A, Li M, Schoch HG, McCune JS (2008) Pharmacogenomic associations in ABCB1 and CYP3A5 with acute kidney injury and chronic kidney disease after myeloablative hematopoietic cell transplantation. Pharmacogenomics J 8:248-255. http://doi.org/10.1038/sj.tpj.6500472

28. Metalidis C, Lerut E, Naesens M, Kuypers DR (2011) Expression of CYP3A5 and P-glycoprotein in renal allografts with histological signs of calcineurin inhibitor nephrotoxicity. Transplantation 91:1098-1102. http://doi.org/10.1097/TP.0b013e3182177502

29. Bosó V, Herrero MJ, Bea S, Galiana M, Marrero P, Marqués MR, Hernández J, Sánchez-Plumed J, Poveda JL, Aliño SF (2013) Increased hospital stay and allograft dysfunction in renal transplant recipients with Cyp2c19 AA variant in SNP rs4244285. Drug Metab Dispos 41:480-487. http://doi.org/10.1124/dmd.112.047977

30. Flahault A, Anglicheau D, Loriot MA, Thervet E, Pallet N (2017) Clinical impact of the CYP3A5 6986A>G allelic variant on kidney transplantation outcomes. Pharmacogenomics 18:165-173. http://doi.org/10.2217/pgs-2016-0146 
31. Woillard JB, Gatault P, Picard N, Arnion H, Anglicheau D, Marquet P (2018) A donor and recipient candidate gene association study of allograft loss in renal transplant recipients receiving a tacrolimus-based regimen. Am J Transplant 18:2905-

2913. http://doi.org/10.1111/ajt.14894

32. Khan AR, Raza A, Firasat S, Abid A (2020) CYP3A5 gene polymorphisms and their impact on dosage and trough concentration of tacrolimus among kidney transplant patients: A systematic review and meta-analysis. Pharmacogenomics J 20:553-

562. http://doi.org/10.1038/s41397-019-0144-7

33. van Gelder T, Meziyerh S, Swen JJ, de Vries APJ, Moes D (2020) The clinical impact of the C 0 /D ratio and the CYP3A5 genotype on outcome in tacrolimus treated kidney transplant recipients. Front Pharmacol 11:1142. http://doi.org/10.3389/fphar.2020.01142

34. Jouve T, Fonrose X, Noble J, Janbon B, Fiard G, Malvezzi P, Stanke-Labesque F, Rostaing L (2020) The TOMATO study (Tacrolimus Metabolization in Kidney Transplantation): Impact of the concentration-dose ratio on death-censored graft survival. Transplantation 104:1263-1271. http://doi.org/10.1097/tp.0000000000002920

\section{Tables}

Table 1 Baseline demographic characteristics of LTx patients stratified by CYP3A5 genotype $(n=90)$ 


\begin{tabular}{|c|c|c|c|c|}
\hline Parameters & All & CYP $3 A 5^{\star} 1$ carriers & $C Y P 3 A 5 * 3 / * 3$ & $p$ \\
\hline n (\%) & $90(100.0)$ & $42(46.7)$ & $48(53.3)$ & \\
\hline Age (years) & $60(56-64)$ & $60(53-64)$ & $60(56-64)$ & 0.890 \\
\hline Male, n (\%) & $79(87.8)$ & $36(85.7)$ & $43(89.6)$ & 0.576 \\
\hline $\mathrm{BMI}\left(\mathrm{kg} / \mathrm{m}^{2}\right)$ & $21.6 \pm 3.9$ & $20.63 \pm 3.44$ & $22.36 \pm 4.17$ & 0.036 \\
\hline Diagnosis (n (\%)) & & & & 0.428 \\
\hline COPD & $16(17.8)$ & $10(23.8)$ & $6(12.5)$ & \\
\hline ILD & $60(66.7)$ & $27(64.3)$ & $33(68.8)$ & \\
\hline $\mathrm{PH}$ & $10(11.1)$ & $3(7.1)$ & $7(14.6)$ & \\
\hline Others & $4(4.4)$ & $2(4.8)$ & $2(4.2)$ & \\
\hline \multicolumn{5}{|l|}{ Comorbidities (n (\%)) } \\
\hline Hypertension & $16(17.8)$ & $4(9.5)$ & $12(25.0)$ & 0.055 \\
\hline Diabetes mellitus & $30(33.3)$ & $9(21.4)$ & $21(43.8)$ & 0.025 \\
\hline Hyperlipidemia & $7(7.8)$ & $3(7.1)$ & $4(8.3)$ & 0.833 \\
\hline Transplant type (n (\%)) & & & & 0.116 \\
\hline Unilateral & $59(65.6)$ & $24(57.1)$ & $35(72.9)$ & \\
\hline Bilateral & $31(34.4)$ & $18(42.9)$ & $13(27.1)$ & \\
\hline $\mathrm{SCr}(\mu \mathrm{mol} / \mathrm{L})$ & $53.8(44.5-66.6)$ & $51.3(42.4-65.1)$ & $56.0(47.8-67.6)$ & 0.070 \\
\hline ALT (IU/L) & $18(14-27)$ & $20(15-37)$ & $17(14-26)$ & 0.486 \\
\hline AST (IU/L) & $20(16-23)$ & $20(17-23)$ & $19(15-24)$ & 0.377 \\
\hline Tbil ( $\mu \mathrm{mol} / \mathrm{L})$ & $6.34(4.74-10.20)$ & $6.28(4.63-11.44)$ & $6.54(4.89-9.74)$ & 0.875 \\
\hline $\mathrm{Dbil}(\mu \mathrm{mol} / \mathrm{L})$ & $2.40(1.70-3.06)$ & $2.24(1.63-2.80)$ & $2.68(1.88-3.72)$ & 0.042 \\
\hline Urea (mmol/L) & $6.22 \pm 1.86$ & $6.08 \pm 1.73$ & $6.33 \pm 1.97$ & 0.531 \\
\hline Uric acid $(\mu \mathrm{mol} / \mathrm{L})$ & $250(194-338)$ & $244(186-291)$ & $268(200-355)$ & 0.161 \\
\hline $\mathrm{RBC}\left(\times 10^{12}\right.$ cells $\left./ \mathrm{L}\right)$ & $4.50(4.03-4.94)$ & $4.52(4.12-4.96)$ & $4.48(3.90-4.90)$ & 0.428 \\
\hline Hemoglobin $(g / L)$ & $137(125-148)$ & $141(126-149)$ & $135(125-147)$ & 0.409 \\
\hline Hematocrit (\%) & $41.40(37.68-44.55)$ & $42.50(37.95-45.32)$ & $40.30(37.38-43.85)$ & 0.204 \\
\hline Glucose (mmol/L) & $6.68(5.19-8.22)$ & $6.70(5.05-8.26)$ & $6.60(5.65-8.21)$ & 0.582 \\
\hline
\end{tabular}

Categoric data are presented as number (\%), continuous data are presented as mean with SD or median with IQR, depending on variable distribution

Table 2 Influence of use of azole antifungals on Tac metabolism 


\begin{tabular}{|c|c|c|c|c|c|c|c|c|}
\hline & \multicolumn{2}{|c|}{ Week $1(n=81)$} & \multicolumn{2}{|c|}{ Week $2(n=84)$} & \multicolumn{2}{|c|}{ Week $3(n=86)$} & \multicolumn{2}{|c|}{ Week $4(n=81)$} \\
\hline & $\begin{array}{l}\text { Antifungals } \\
(-)\end{array}$ & $(+)$ & $\begin{array}{l}\text { Antifungal } \\
(-)\end{array}$ & $(+)$ & $\begin{array}{l}\text { Antifungals } \\
(-)\end{array}$ & $(+)$ & $\begin{array}{l}\text { Antifungals } \\
(-)\end{array}$ & \\
\hline$n$ & 70 & 11 & 67 & 17 & 63 & 23 & 55 & 26 \\
\hline $\begin{array}{l}\text { Concentration } \\
\text { (ng/mL) }\end{array}$ & $\begin{array}{l}5.8(2.4- \\
10.2)\end{array}$ & $\begin{array}{l}11.0 \\
(9.3- \\
17.4)^{*}\end{array}$ & $\begin{array}{l}6.6 \\
(5.3- \\
8.9)\end{array}$ & $\begin{array}{l}10.4 \\
(7.1- \\
13.6)^{*}\end{array}$ & $\begin{array}{l}7.4(6.2- \\
9.9)\end{array}$ & $\begin{array}{l}8.4(6.9- \\
10.9)\end{array}$ & $\begin{array}{l}7.7(6.3- \\
9.0)\end{array}$ & $\begin{array}{l}8.8(6.4- \\
10.5)\end{array}$ \\
\hline Dose (mg/d) & $\begin{array}{l}2.0(2.0- \\
3.0)\end{array}$ & $\begin{array}{l}1.0(1.0- \\
1.5)^{*}\end{array}$ & $\begin{array}{l}3.5 \\
(2.0- \\
5.5)\end{array}$ & $\begin{array}{l}0.5(0.5- \\
2.0)^{*}\end{array}$ & $\begin{array}{l}4.0(2.5- \\
6.0)\end{array}$ & $\begin{array}{l}1.0(0.5- \\
1.0)^{*}\end{array}$ & $\begin{array}{l}4.5(2.5- \\
6.5)\end{array}$ & $\begin{array}{l}1.0(0.5- \\
1.0)^{*}\end{array}$ \\
\hline $\begin{array}{l}\text { C/D (ng/mL } \\
\text { per mg/d) }\end{array}$ & $\begin{array}{l}134.10 \\
(68.42- \\
238.99)\end{array}$ & $\begin{array}{l}693.00 \\
(417.60- \\
1000.50) \\
*\end{array}$ & $\begin{array}{l}129.00 \\
(71.84- \\
230.14)\end{array}$ & $\begin{array}{l}745.20 \\
(506.35- \\
1148.35) \\
*\end{array}$ & $\begin{array}{l}122.01 \\
(62.66- \\
215.78)\end{array}$ & $\begin{array}{l}678.00 \\
(320.17- \\
938.40)\end{array}$ & $\begin{array}{l}121.60 \\
(59.40- \\
187.25)\end{array}$ & $\begin{array}{l}525.60 \\
(277.48- \\
885.96)^{*}\end{array}$ \\
\hline
\end{tabular}

Categoric data are presented as number (\%), continuous data presented as mean with SD or median with IQR, depending on variable distribution. ${ }^{*}$ indicates the level of significance $(p<0.05)$

Table 3 Odds ratio (OR) with 95\% confidence interval (Cl) for risk factors of AKI incidence

\begin{tabular}{lllll} 
& Univariate analysis & \multicolumn{2}{c}{ Multivariate analysis } \\
\hline Variables & OR $(95 \% \mathrm{Cl})$ & $p$ & OR $(95 \% \mathrm{Cl})$ & $p$ \\
\hline Age & $0.96(0.91-1.02)$ & 0.179 & & \\
\hline $\mathrm{SCr}, \mu \mathrm{mol} / \mathrm{L}$ & $0.98(0.95-1.01)$ & 0.192 & & \\
\hline Uric acid, $\mu \mathrm{mol} / \mathrm{L}$ & $1.00(1.00-1.01)$ & 0.088 & & \\
\hline $\mathrm{RBC}, \times 10^{12} \mathrm{cell} / \mathrm{L}$ & $1.71(0.80-3.66)$ & 0.165 & & \\
\hline Week 1 Tac concentration $\geq 7.5 \mathrm{ng} / \mathrm{ml}$ & $5.38(1.40-20.69)$ & 0.014 & $5.38(1.40-20.69)$ & 0.014
\end{tabular}

\section{Figures}



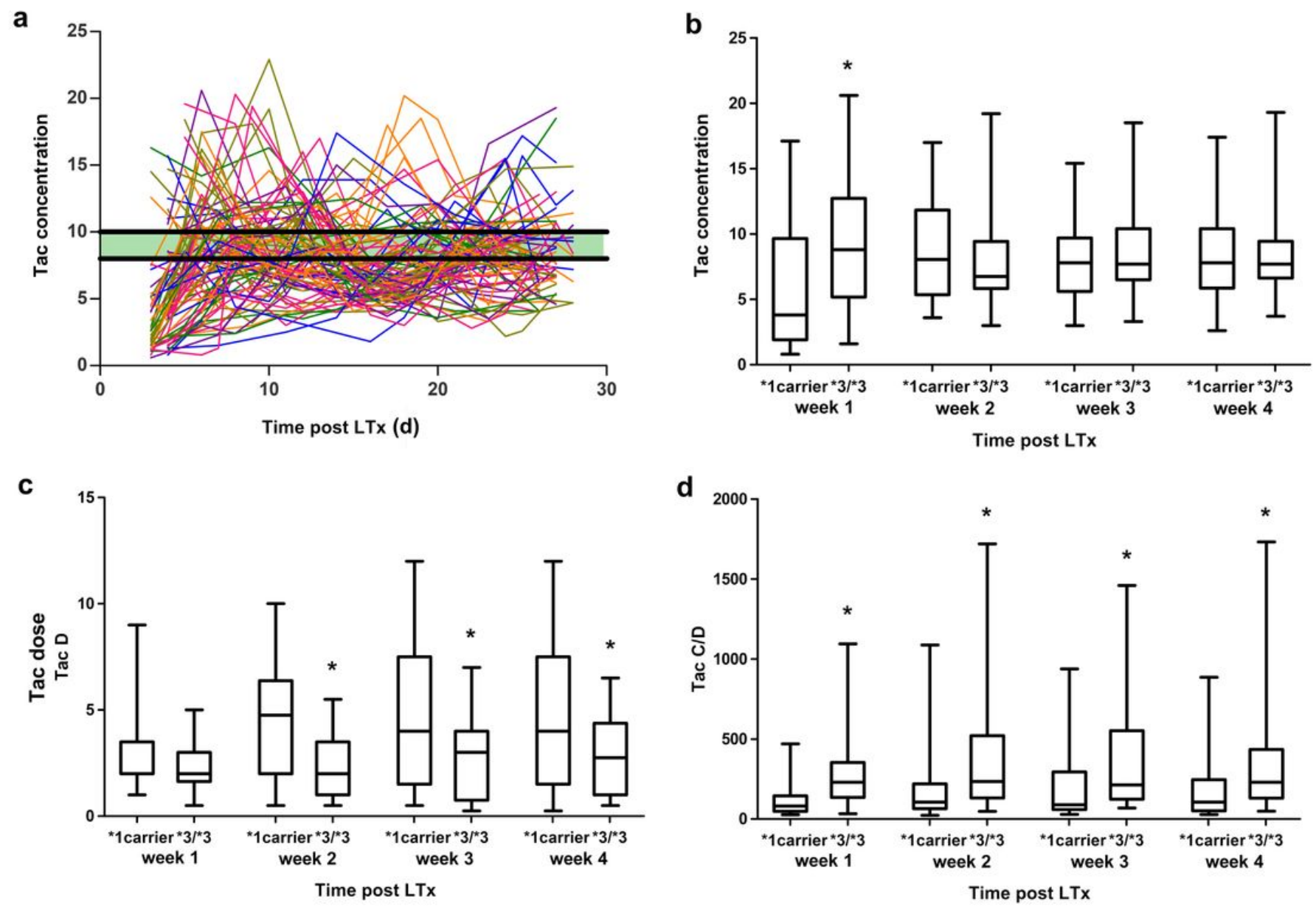

Figure 1

(a) Tac concentration trend-lines of LTx patients during POD 3-28 ( $n=90,685$ trough concentrations). Green shaded frame indicates the target range 8-10 ng/mL. Influence of CYP3A5 genotype on Tac concentration (b), dose (c) and C/D (d). Boxes and black lines in boxes represent IQR and median values, respectively; whiskers represent highest and lowest values. * indicates $p<0.05$ 
a

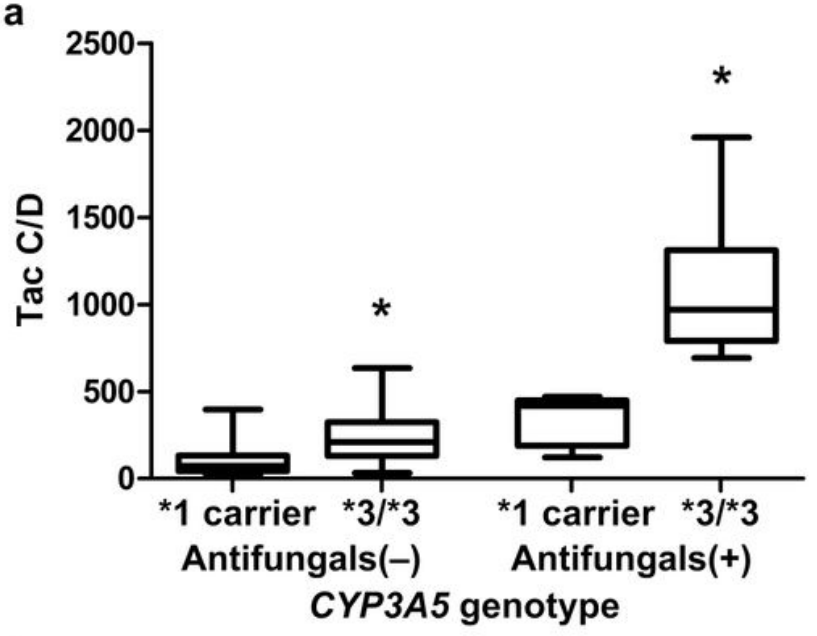

c

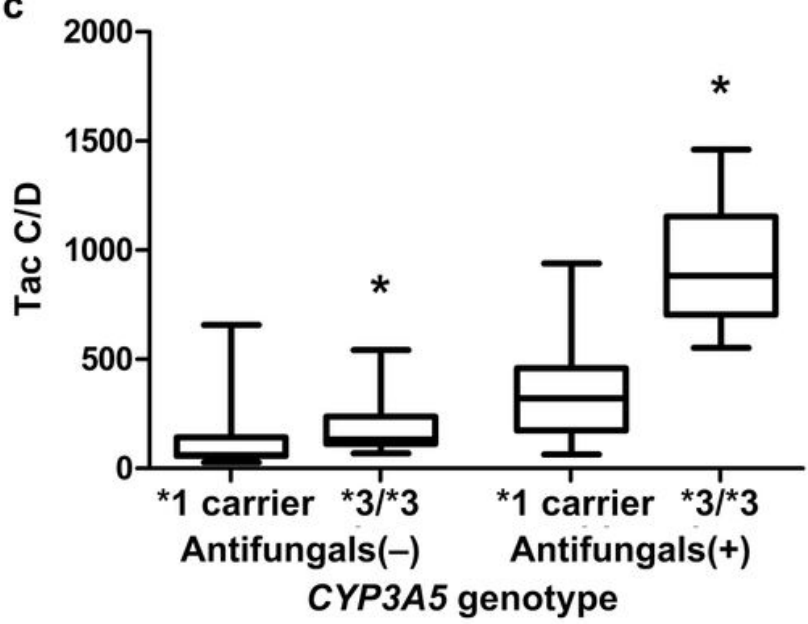

b

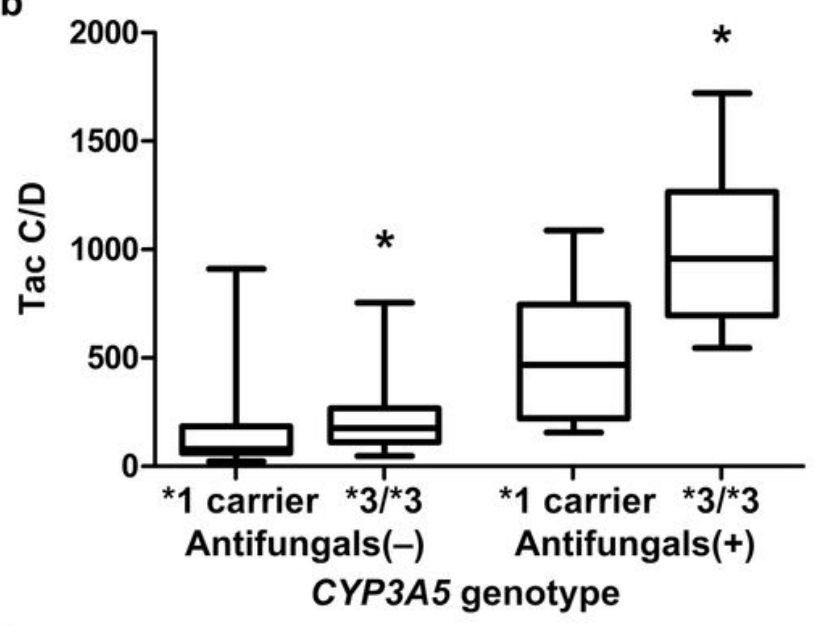

d

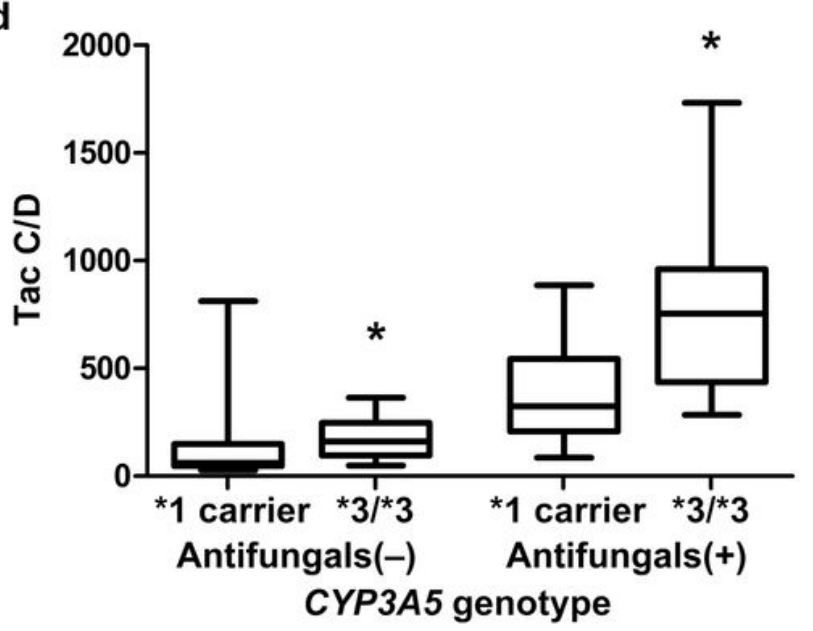

Figure 2

Influence of CYP3A5 genotype and use of azole antifungals on Tac concentration in post-operative week 1 (a) ( $\mathrm{n}=81$, CYP3A5*1 carriers: $n=37, * 3 / * 3: n=44)$, week 2 (b) ( $n=84$, CYP3A5*1 carriers: $n=40, * 3 / * 3: n=44)$, week 3 (c) ( $n=86, C Y P 3 A 5 * 1$ carriers: $n=39$, *3/*3: $n=47)$ and week $4(d)(n=81$, CYP3A5*1 carriers: $n=37, * 3 / * 3: n=44)$. CYP3A5*1 carriers had higher concentration in week 1 compared with CYP3A5*3/*3 group (Mann-Whitney $U$ test). Use of azole antifungals did not change the influence of CYP3A5 genotype on Tac concentration. * indicates $p<0.05$
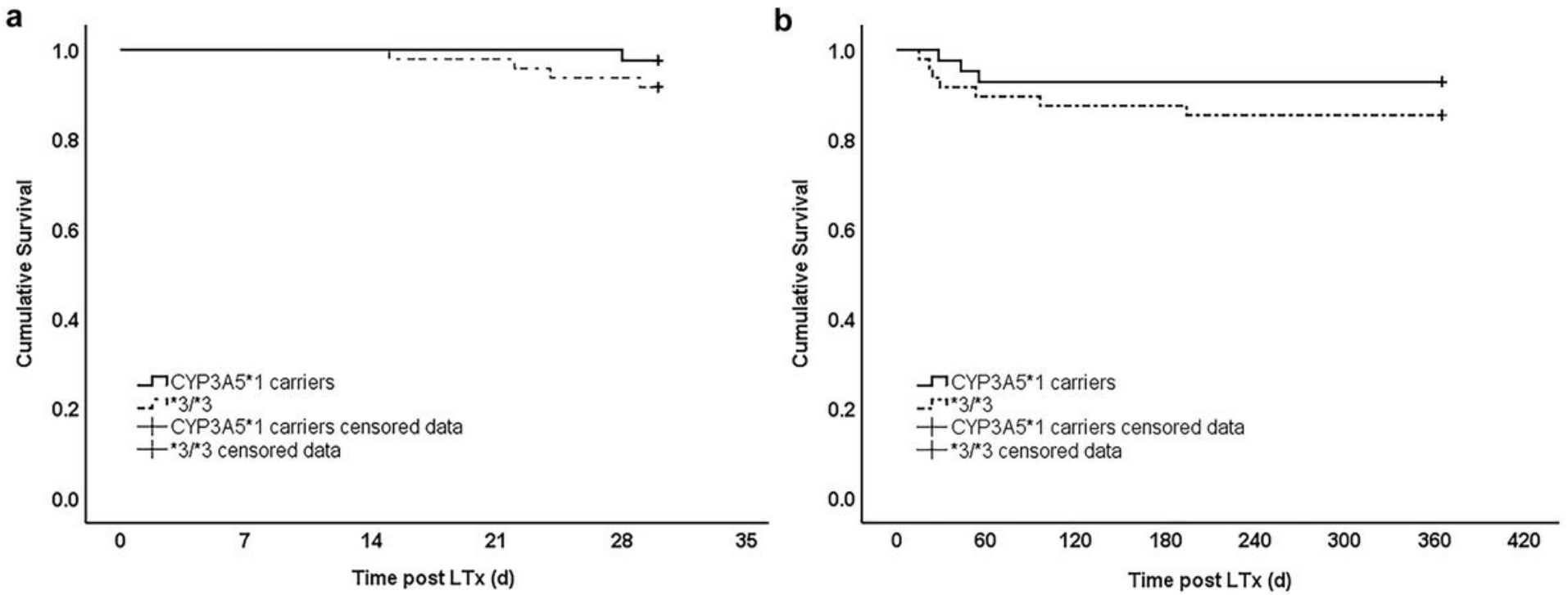
Figure 3

Kaplan-Meier survival curves stratified by CYP3A5 genotypes at 30-day (a) and 1-year (b)

\section{Supplementary Files}

This is a list of supplementary files associated with this preprint. Click to download.

- Supplementaryfiles.docx 